\title{
Canola meal replacing distillers grains with solubles for lactating dairy cows
}

\author{
C. N. Mulrooney, D. J. Schingoethe, ${ }^{1}$ K. F. Kalscheur, and A. R. Hippen \\ Dairy Science Department, South Dakota State University, Brookings 57007-0647
}

\begin{abstract}
A study was conducted to determine the response to feeding diets containing canola meal $(\mathrm{CM})$ as a protein supplement in place of all or portions of dried distillers grains with solubles (DDGS). Twelve lactating Holstein cows (4 primiparous and 8 multiparous) were fed in a $4 \times 4$ Latin square design over 4 -wk periods. Data were collected wk 3 and 4 of each period. Diets were formulated in which CM was $100,66,33$, and $0 \%$ of the supplemental protein replacing the protein from DDGS. All diets (averaged $15.1 \%$ crude protein and $4.5 \%$ ether extract) contained $55 \%$ forage and $45 \%$ concentrate, with the forage being $50 \%$ corn silage and $50 \%$ alfalfa hay. Dry matter intake $(25.4 \mathrm{~kg} / \mathrm{d})$ was similar for all diets. Milk production $(35.2,35.8,34.5$, and $34.3 \mathrm{~kg} / \mathrm{d}$, respectively, for $100,66,33$, and $0 \% \mathrm{CM}$ ) was similar for all diets, but tended to be greater with higher proportions of CM. Milk protein concentration (3.04\%), fat concentration $(3.92 \%)$, and fat yield $(1.37 \mathrm{~kg} / \mathrm{d})$ were similar for all diets, whereas protein yield (1.08, $1.10,1.05$, and $1.03 \mathrm{~kg} / \mathrm{d}$, respectively, for 100,66 , 33 , and $0 \% \mathrm{CM}$ ) tended to be greater with increasing amounts of $\mathrm{CM}$ in the diet. Feed efficiency $(1.46 \mathrm{~kg}$ of energy-corrected milk/ $\mathrm{kg}$ of dry matter intake) was similar for all diets. Lysine was the first limiting amino acid for milk protein synthesis when CM or DDGS were fed, whereas methionine was first limiting when the combination diets were fed. Concentrations of ammonia and volatile fatty acids in ruminal contents were similar for all diets. Canola meal is a suitable replacement for DDGS in dairy cow diets.
\end{abstract}

Key words: canola meal, distillers grain with solubles, lactating dairy cow

\section{INTRODUCTION}

Continual growth of the ethanol industry has resulted in large quantities of byproducts available for livestock feed, such as dried distillers grains with solubles

Received April 3, 2009.

Accepted July 22, 2009.

${ }^{1}$ Corresponding author: david.schingoethe@sdstate.edu
(DDGS). When DDGS is fed to lactating cows, milk production is usually equal to or higher than production achieved with other protein supplements such as soybean meal (Nichols et al., 1998; Anderson et al., 2006; Schingoethe, 2008). Canola meal (CM), produced primarily in Canada and the northern United States, is a good-quality protein supplement that is becoming increasingly available (Piepenbrink and Schingoethe, 1998). Unlike DDGS and other corn-based products, which are limiting in Lys (Nichols et al., 1998; Schingoethe, 2008), CM, although degraded more extensively in the rumen, has one of the highest biological values of all vegetable protein supplements available (Schingoethe, 1996; Piepenbrink and Schingoethe, 1998). When Sánchez and Claypool (1983) compared CM, cottonseed meal, and soybean meal as a protein source for cows during early lactation, they observed a tendency for cows fed the CM to have higher milk production but milk components and feed intake were not affected. Maesoomi et al. (2006) reported higher milk protein percentages and higher digestibility of DM and $\mathrm{CP}$ when $\mathrm{CM}$ replaced cottonseed meal in the diet. Piepenbrink et al. (1998) observed similar milk production when CM was fed as the protein supplement as when CM was fed in combination with other highquality protein sources that included blood meal, corn gluten meal, and fish meal. When Brito and Broderick (2007) compared urea to soybean meal, cottonseed meal, and CM for potential benefits of the various protein supplements, the latter 3 true protein supplements were superior to urea as $\mathrm{CP}$ sources, improving feed intake and yields of milk fat and protein.

When it comes to rumen degradability, the protein in DDGS (RUP $=55-65 \%$ of CP; Kleinschmit et al., 2007a; Schingoethe, 2008) may degrade less in the rumen than desired for optimal protein utilization, whereas CM (RUP $=28-40 \%$ of CP; Piepenbrink and Schingoethe, 1998; NRC, 2001) is more ruminally degradable. This, in addition to the Lys limitation of DDGS and the generally more desirable biological value of the protein in CM (Schingoethe, 1996), causes one to consider that some combination of DDGS and CM as protein sources may be optimal for milk protein production. Thus, this research was conducted to determine whether either CM or DDGS alone or a combination of the 2 sources 
Table 1. Ingredient composition of experimental diets

\begin{tabular}{lrrrr}
\hline & \multicolumn{4}{c}{ Diet $^{1}$} \\
\cline { 2 - 5 } Item, \% of DM & CM & $2 / 3 \mathrm{CM}$ & $1 / 3 \mathrm{CM}$ & DDGS \\
\hline Corn silage & 27.50 & 27.50 & 27.50 & 27.50 \\
Alfalfa hay & 27.50 & 27.50 & 27.50 & 27.50 \\
Corn grain, ground, dry & 34.92 & 33.90 & 33.00 & 31.76 \\
Canola meal, 44\% CP & 6.63 & 4.59 & 2.29 & 0.00 \\
DDGS, 31\% CP & 0.00 & 3.24 & 6.63 & 10.40 \\
Trace mineral salt $^{2}$ & 0.60 & 0.61 & 0.62 & 0.61 \\
Fat $^{3}$ & 1.60 & 1.41 & 1.21 & 1.00 \\
Limestone $_{\text {Dicalcium phosphate }}$ & 0.60 & 0.60 & 0.60 & 0.60 \\
Vitamin A, D, and E mix $^{4}$ & 0.40 & 0.40 & 0.40 & 0.40 \\
Vitamin E mix & 0.20 & 0.20 & 0.20 & 0.20 \\
& 0.05 & 0.05 & 0.05 & 0.05 \\
\hline
\end{tabular}

${ }^{1}$ Diets include canola meal $(\mathrm{CM}) ; 2 / 3$ canola meal and $1 / 3$ dried distillers grains with solubles $(2 / 3 \mathrm{CM}) ; 1 / 3$ canola meal and $2 / 3$ dried distillers grains with solubles $(1 / 3 \mathrm{CM})$; and dried distillers grains with solubles (DDGS).

${ }^{2}$ Guaranteed analysis (mg $/ \mathrm{kg}$ ): 940,000-985,000 NaCl, 387,000 Na, 2,000 Fe, 3,500 Zn, 2,000 Mn, $300 \mathrm{Cu}, 70 \mathrm{I}$, and $50 \mathrm{Co}$.

${ }^{3}$ Energy Booster 100, Milk Specialties Co., Dundee, IL.

${ }^{4}$ Mix included 2,500 kIU/ $\mathrm{kg}$ of vitamin $\mathrm{A}, 400 \mathrm{kIU} / \mathrm{kg}$ of vitamin D, and $1,000 \mathrm{IU} / \mathrm{kg}$ of vitamin $\mathrm{E}$.

${ }^{5}$ Mix included 44,000 IU/kg of vitamin E.

would be the most effective for increasing milk production of lactating cows.

\section{MATERIALS AND METHODS}

\section{Experimental Plan}

Eight multiparous $(111 \pm 18$ DIM $)$ and 4 primiparous (106 \pm 8 DIM) lactating Holstein cows were used in a trial to evaluate and compare different proportions of CM and DDGS used as protein supplements. Cows were blocked into squares based on parity, DIM, and milk production, and within blocks were randomly assigned to 1 of 4 experimental diets in a replicated $4 \times$ 4 Latin square design. Cows were housed in a freestall barn and fed diets as a TMR with a Calan Broadbent feeder door and box system (American Calan Inc., Northwood, NH) and were cared for in accordance with the South Dakota State University Animal Care and Use policy. Prior to the start of the trial, there was a 10-d period for the cows to adapt to the feeding system. Experimental periods were $4 \mathrm{wk}$ long, with the initial 2 wk for adaptation and wk 3 and 4 for data collection.

Four dietary treatments were used to evaluate supplemental proteins as follows: canola meal as the sole source of supplemental protein (CM), 2/3 canola meal and $1 / 3$ DDGS $(\mathbf{2} / \mathbf{3 C M}), 1 / 3$ canola meal and $2 / 3$ DDGS (1/3CM), and DDGS. Diets (Table 1) were formulated to be similar in CP $(16.0 \%)$ and ether extract (EE; $4.7 \%)$ and to meet or exceed suggested requirements (NRC, 2001) for various minerals and vitamins. Diets were balanced for equal fat content so that comparisons between CM and DDGS would be truly on the protein contents of both ingredients. All diets had a forage:concentrate ratio of $55: 45$, with the forage DM equally from alfalfa hay and corn silage. Forages for all diets were premixed in a vertical mixer wagon (1999 NDE 500, Westside Implement, Clark, $\mathrm{SD})$. Concentrate mix was added to the Calan Data Ranger (American Calan Inc.) after addition of the forage premix.

\section{Experimental Measures}

Feed intake for individual cows was measured daily using the Calan Broadbent feeder door system and Data Ranger. At the end of each week, samples of corn silage, alfalfa hay, DDGS, CM, concentrate mixes, and diets were collected and stored at $-20^{\circ} \mathrm{C}$ until analysis. The DM concentrations were determined weekly by drying samples of wet feed components at $105^{\circ} \mathrm{C}$ for 2 to $4 \mathrm{~h}$ according to AOAC method 930.15 (AOAC, 2002) so that as fed amounts of ingredients could be adjusted to ensure proper inclusion of ingredients. All samples were composited by period and dried at $55^{\circ} \mathrm{C}$ for $48 \mathrm{~h}$ in a Despatch oven (style V-23, Despatch Oven Co., Minneapolis, MN). Composites were first ground through a 4-mm screen on a Wiley mill (model 3, Arthur H. Thomas., Philadelphia, PA) and then reground through an ultracentrifuge mill with a 1-mm screen (Brinkman Instruments Co., Westbury, NY). All feed samples were analyzed for true DM, ash, NDF, ADF, EE, and CP. Additionally, total study composites were made of CM, DDGS, and all TMR and analyzed for $\mathrm{Ca}, \mathrm{P}, \mathrm{Mg}, \mathrm{K}$, and $\mathrm{S}$ contents by spectroscopic method and Corning Direct Reading Chloride/Salt analyzer (AOAC, 2002; methods 965.09 and 985.01).

True DM of samples was determined by drying approximately $1 \mathrm{~g}$ of sample at $105^{\circ} \mathrm{C}$ for 2 to $4 \mathrm{~h}$. Ash was determined by heating samples for $8 \mathrm{~h}$ at $450^{\circ} \mathrm{C}$ in a muffle furnace (Understander et al., 1993). Samples were analyzed sequentially for NDF and ADF via Ankom filter bag analysis system (Ankom Technology Corp., Fairport, NY). The NDF analysis was based on procedures described by Van Soest et al. (1991) that use heat-stable $\alpha$-amylase and sodium sulfite; ADF analysis was based on procedures described in Robertson and Van Soest (1981). Ether extract was determined using the Ankom filter bag analysis system (Ankom Technology Corp.) according to procedure AM 5-04 (AOAC, 2002). Crude protein was determined using Elementar rapid $\mathrm{N}$-cube $\mathrm{N}$ determination (Elementar Americas Inc., Mt. Laurel, NJ), based on AOAC method 993.13 (AOAC, 2002).

Cows were milked daily at 0600, 1400, and $2100 \mathrm{~h}$, and individual milk production was recorded at each 
milking. Milk samples were collected from each milking on 2 consecutive days at the end of wk 3 and 4 of each period. Milk samples were mixed via inversion and composited by day corresponding to the respective milk weights from each milking. Samples were sent to Heart of America DHIA Laboratory (Manhattan, KS) for analysis of fat, protein, lactose, somatic cells, and MUN according to AOAC (2002) procedures. The fat, protein, and lactose components were analyzed by midinfrared spectroscopy (Bentley 2000 Infrared Milk Analyzer, Bentley Instruments, Chaska, MN). Milk urea N concentration was determined using chemical methods based on a modified Berthelot reaction (AOAC, 2002; ChemSpec 150 Analyzer, Bentley Instruments). The SCC was determined with a flow cytometer laser (Somacount 500, Bentley Instruments). Energy-corrected milk was determined using the equation $(0.327 \times \mathrm{kg}$ of milk $)+(12.95 \times \mathrm{kg}$ of fat $)+(7.2 \times \mathrm{kg}$ of protein $)$ (Orth, 1992).

Cows were weighed on each of $3 \mathrm{~d}$ before the beginning of the trial and on each of the last $3 \mathrm{~d}$ of each period. The BCS, determined using a scale of 1 to 5 (Wildman et al., 1982), were recorded by 3 independent individuals at the start of the trial and at the end of each period.

On $1 \mathrm{~d}$ in wk 4 of each period, approximately 2 to 3 $\mathrm{h}$ postfeeding, rumen fluid was collected via an esophageal tube fitted with a filter on the rumen end and a hand-operated pump. Approximately $250 \mathrm{~mL}$ of rumen fluid was discarded before sample collection to minimize contamination with saliva. Ten-milliliter aliquots of rumen fluid were mixed with $2 \mathrm{~mL}$ of $25 \%$ (wt/ vol) metaphosphoric acid and frozen at $-20^{\circ} \mathrm{C}$ until analysis. Rumen fluid samples were analyzed for ammonia $\mathrm{N}$ concentration using the procedure described by Chaney and Marbach (1962). Concentrations of VFA were measured using a gas chromatograph (model 6890, Hewlett-Packard, Avondale, PA) equipped with a column measuring 0.25-mm i.d. $\times$ 15-m (Nukol, 17926 to $01 \mathrm{C}$, Supelco Inc., Bellefonte, PA). The split ratio in the injector port $\left(250^{\circ} \mathrm{C}\right)$ was $100: 1$ with a He flow of $1.3 \mathrm{~mL} / \mathrm{min}$. Detector and column temperatures were maintained at $225^{\circ} \mathrm{C}$ and $130^{\circ} \mathrm{C}$, respectively.

Blood was sampled from a coccygeal vessel and a subcutaneous abdominal vein into vacuum tubes containing heparin (Becton Dickinson Vacutainer Systems, Rutherford, NJ) approximately 2 to $3 \mathrm{~h}$ after feeding on $1 \mathrm{~d}$ of wk 4 of each period. The samples were immediately placed on ice and transported to the laboratory, where they were centrifuged and the plasma was separated and stored at $-20^{\circ} \mathrm{C}$ for $\mathrm{AA}$ analysis. The soluble protein in the plasma was precipitated with sulfosalicylic acid and removed by centrifugal filtration. The plasma was diluted with a lithium citrate buffer.
Samples were analyzed for AA via HPLC (model 1100, Aligent Technologies Inc., Palo Alto, CA) with a PCX 5200 post-column derivatizer (Pickering Laboratories Inc., Mountain View, CA); analysis was conducted using an isothermal 3-buffer lithium HPLC gradient elution format as described by Mondina et al. (1972), Pickering (1989), and Grunau and Swiader (1992).

\section{Statistical Analysis}

Analysis was performed on period means of DMI, milk yield, and milk composition during wk 3 and 4 of each period, and on means of plasma AA concentrations, rumen ammonia, and VFA during wk 4 of each period. Data were analyzed using the MIXED procedure of SAS (version 9.1, SAS Institute, Cary, NC). The experimental model used cow as the experimental unit and cow (parity) as the random variable:

$$
\begin{gathered}
\mathrm{Y}=\text { Treatment }+ \text { Parity }+ \text { Treatment } \\
\times \text { Parity }+ \text { Period }
\end{gathered}
$$

Essentially all interactions were deemed insignificant and were removed from the model. Linear, quadratic, and cubic effects were compared and significance was declared at $P<0.05$, and tendencies indicated at $P<$ 0.10 .

\section{RESULTS AND DISCUSSION}

\section{Nutrient Content of Diets}

The chemical composition of the diet ingredients and diets is presented in Table 2. Corn silage was wetter than desired $(25.5 \%$ DM) but appeared to have had normal fermentation. The EE values for alfalfa hay and corn silage were lower than expected based on NRC (2001) data, which could account for the diet EE values that were somewhat lower than expected. All diets were slightly lower in $\mathrm{CP}$ than anticipated $(\sim 15.1 \% \mathrm{CP}$ vs. $16 \% \mathrm{CP}$ ). This was primarily because the protein content of the alfalfa hay and corn silage was slightly lower than it was in the preliminary sample analyses. However, this lower CP content of the diets actually allowed for a better evaluation of the 2 supplemental protein sources. The mineral composition was similar for all diets.

Overall, based on the NRC (2001) model, the estimated MP $(52.9,52.8,52.2$, and $52.2 \%$ of CP for CM, 2/3CM, 1/3CM, and DDGS diets, respectively) was slightly higher when there were greater amounts of CM protein in the diet. Likewise, estimated Lys content of MP (6.4, 6.3, 6.1, and 6.0\%, respectively) was higher with greater amounts of $\mathrm{CM}$ in the diet. 
Table 2. Nutrient composition (\% of DM unless otherwise noted) of alfalfa hay, corn silage, concentrate mixes, canola meal (CM), dried distillers grains with solubles (DDGS), and TMR for experimental diets

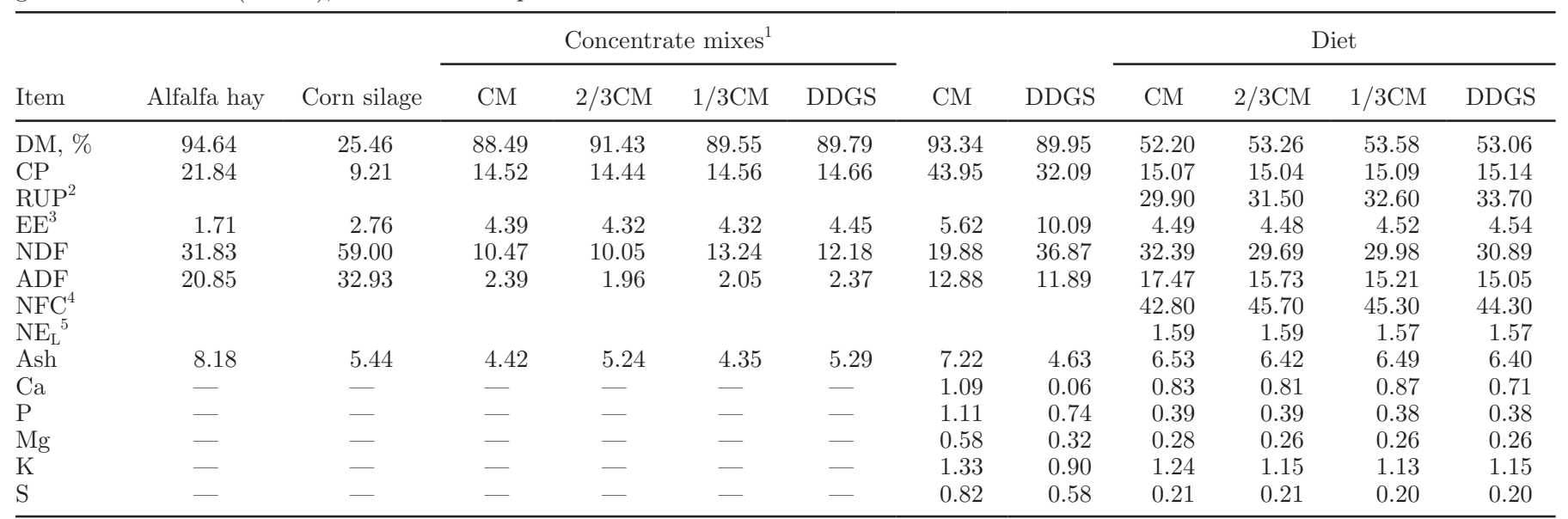

${ }_{1}^{1} / 3 \mathrm{CM}=2 / 3$ canola meal and $1 / 3$ dried distillers grains with solubles; $1 / 3 \mathrm{CM}=1 / 3$ canola meal and $2 / 3$ dried distillers grains with solubles.

${ }^{2}$ Percent of CP, estimated from NRC (2001).

${ }^{3} \mathrm{EE}=$ ether extract.

${ }^{4} \mathrm{NFC}=100-(\mathrm{NDF}+\mathrm{CP}+\mathrm{EE}+\mathrm{ash})$.

${ }^{5} \mathrm{NE}_{\mathrm{L}}, \mathrm{Mcal} / \mathrm{kg}$, estimated from NRC (2001).

\section{DMI and Lactational Response}

The DMI (Table 3) was similar for all diets, a result similar to that of previous research with DDGS (Anderson et al., 2006; Kleinschmit et al., 2007b) and CM (Maesoomi et al., 2006; Brito and Broderick, 2007). The addition of CM in place of all or portions of DDGS did not affect production of milk or ECM. This finding is consistent with previous research that indicated that CM was comparable to soybean meal and cottonseed meal as a protein source for lactating cows (Sánchez and Claypool, 1983; DePeters and Bath, 1986; Brito and Broderick, 2007). There were no differences between treatments for concentrations and yields of milk fat, protein, and lactose. Although none of the differences in yields of milk or components resulting from diets approached statistical significance, absolute numbers tended to favor higher proportions of CM, especially $2 / 3 \mathrm{CM}$. Somatic cell counts were similar among diets and within normal ranges, indicating no major issues with mastitis.

Table 3. Dry matter intake, milk production, milk composition, BW, and BCS when fed experimental diets

\begin{tabular}{|c|c|c|c|c|c|c|c|c|}
\hline \multirow[b]{2}{*}{ Item } & \multicolumn{4}{|c|}{$\operatorname{Diet}^{1}$} & \multirow[b]{2}{*}{ SEM } & \multicolumn{3}{|c|}{$P$-value } \\
\hline & $\mathrm{CM}$ & $2 / 3 \mathrm{CM}$ & $1 / 3 \mathrm{CM}$ & DDGS & & Linear & Quadratic & Cubic \\
\hline $\mathrm{ECM}, \mathrm{kg} / \mathrm{d}$ & 36.7 & 38.4 & 36.6 & 35.7 & 1.60 & 0.32 & 0.21 & 0.33 \\
\hline Fat, \% & 3.81 & 4.05 & 3.97 & 3.87 & 0.16 & 0.86 & 0.21 & 0.59 \\
\hline Fat, $\mathrm{kg} / \mathrm{d}$ & 1.34 & 1.45 & 1.37 & 1.32 & 0.07 & 0.54 & 0.17 & 0.37 \\
\hline Lactose, $\%$ & 4.91 & 4.86 & 4.87 & 4.92 & 0.04 & 0.68 & 0.09 & 0.91 \\
\hline Lactose, $\mathrm{kg} / \mathrm{d}$ & 1.72 & 1.76 & 1.67 & 1.69 & 0.08 & 0.37 & 0.76 & 0.23 \\
\hline MUN, mg/dL & 7.10 & 7.56 & 7.63 & 7.25 & 0.20 & 0.53 & 0.03 & 0.93 \\
\hline $\mathrm{SCC}, 10^{3}$ cells $/ \mathrm{mL}$ & 150.8 & 196.3 & 104.6 & 143.2 & 63.43 & 0.49 & 0.94 & 0.22 \\
\hline $\mathrm{FE}^{2}$ & 1.46 & 1.53 & 1.42 & 1.44 & 0.06 & 0.41 & 0.55 & 0.11 \\
\hline $\mathrm{BW}, \mathrm{kg}$ & 708 & 711 & 710 & 698 & 22.15 & 0.38 & 0.37 & 0.83 \\
\hline $\mathrm{BCS}^{3}$ & 3.19 & 3.28 & 3.28 & 3.24 & 0.06 & 0.26 & 0.06 & 0.69 \\
\hline
\end{tabular}

${ }^{1}$ Diets include canola meal (CM); $2 / 3$ canola meal and $1 / 3$ dried distillers grains with solubles $(2 / 3 \mathrm{CM}) ; 1 / 3$ canola meal and $2 / 3$ dried distillers grains with solubles $(1 / 3 \mathrm{CM})$; and dried distillers grains with solubles (DDGS).

${ }^{2} \mathrm{FE}=$ feed efficiency $=\mathrm{kg}$ of $\mathrm{ECM} / \mathrm{kg}$ of DMI.

${ }^{3}$ The scale was as follows: $1=$ emaciated and $5=$ overly fat (Wildman et al., 1982). 
There was a quadratic response $(P<0.05)$ in MUN concentrations (Table 3), although it is questionable whether these small differences are biologically significant. Overall, MUN concentrations were low in comparison with recent research that was conducted with diets that contained more CP (Anderson et al., 2006; Brito and Broderick, 2007). Low MUN values indicate a possible protein deficiency, which was expected and actually intended given the formulation of the experimental diets. It was intended for this study to have diets relatively low in protein in order to demonstrate a truer response to dietary protein sources.

Dietary treatments had no effect on feed efficiency (Table 3). As expected, BW (706 kg) and BCS (3.25) were similar among diets, although BCS showed a quadratic trend $(P<0.06)$, being slightly higher with the blend diets.

\section{Blood AA Analysis}

The AA concentrations in the plasma from the coccygeal artery were similar across treatments (Table 4), except for the concentrations of His, Ile, and Lys. Concentrations of His decreased linearly as CM was added to the diets. Piepenbrink et al. (1998) also showed a numerically lower amount of His in CM compared with other protein sources. Histidine is the second-limiting AA in CM relative to milk protein (Piepenbrink and Schingoethe, 1998). Results of Piepenbrink et al. (1998) also supported the linear increase of Ile concentrations as CM was added to the diets. Lysine concentrations decreased with increasing amounts of DDGS in the diet, which reflected the Lys deficiency of corn-based products (Schingoethe, 1996; Nichols et al., 1998; Kleinschmit et al., 2007b). This was not surprising: CM contains more Lys than does DDGS because corn-based products are frequently low in Lys. Although CM and DDGS are virtually the same in Met concentrations, with 1.87 and $1.82 \%$ of $\mathrm{CP}$, respectively, the Lys content of $\mathrm{CM}$ is more than double that of DDGS (5.62 vs. $2.24 \%$ of CP, respectively; NRC, 2001). Because Lys deficiency is one of the larger concerns surrounding DDGS in ruminant diets, an increase in Lys concentration by the addition of $\mathrm{CM}$ to diets could prove to be a major advantage of CM over DDGS. No differences were seen in nonessential AA (NEAA) concentrations or in total NEAA supplied to the mammary gland.

Plasma from the subcutaneous abdominal vein showed very little variation resulting from treatment diets (Table 5). The same differences in His and Ile concentrations were present in this plasma as were present in the arterial plasma, which agreed with past research (Piepenbrink et al., 1998). As observed with arterial plasma, there were no differences seen in NEAA concentrations or total NEAA.

For all EAA and NEAA, arteriovenous differences (Table 6 ) were not affected by dietary treatment. There was a trend $(P=0.07)$ for Lys concentration to increase

Table 4. Amino acid concentrations $(\mu \mathrm{mol} / \mathrm{dL})$ in plasma from the coccygeal artery in lactating dairy cows fed experimental diets

\begin{tabular}{|c|c|c|c|c|c|c|c|c|}
\hline \multirow[b]{2}{*}{ Item } & \multicolumn{4}{|c|}{ Diet $^{1}$} & \multirow[b]{2}{*}{ SEM } & \multicolumn{3}{|c|}{$P$-value } \\
\hline & $\mathrm{CM}$ & $2 / 3 \mathrm{CM}$ & $1 / 3 \mathrm{CM}$ & DDGS & & Linear & Quadratic & Cubic \\
\hline \multicolumn{9}{|c|}{ Essential AA (EAA) } \\
\hline Arg & 9.7 & 9.5 & 8.1 & 8.6 & 0.94 & 0.29 & 0.70 & 0.48 \\
\hline His & 3.6 & 4.1 & 4.4 & 4.5 & 0.76 & 0.02 & 0.41 & 0.92 \\
\hline Ile & 11.1 & 11.1 & 10.0 & 9.5 & 1.45 & 0.03 & 0.71 & 0.55 \\
\hline Leu & 13.7 & 15.2 & 17.2 & 15.4 & 4.22 & 0.37 & 0.35 & 0.59 \\
\hline Lys & 8.0 & 8.0 & 6.9 & 6.4 & 1.12 & $<0.01$ & 0.61 & 0.35 \\
\hline Met & 2.1 & 2.3 & 2.3 & 2.0 & 0.20 & 0.81 & 0.20 & 0.83 \\
\hline Phe & 4.1 & 4.4 & 4.0 & 4.3 & 0.21 & 0.97 & 0.94 & 0.21 \\
\hline Thr & 9.0 & 8.7 & 8.1 & 7.9 & 1.94 & 0.26 & 0.95 & 0.81 \\
\hline Trp & 2.4 & 2.5 & 2.4 & 2.3 & 0.60 & 0.78 & 0.60 & 0.92 \\
\hline Val & 22.1 & 22.7 & 21.7 & 20.4 & 2.84 & 0.25 & 0.40 & 0.80 \\
\hline Total EAA & 86.4 & 89.0 & 85.7 & 81.8 & 11.34 & 0.42 & 0.49 & 0.80 \\
\hline \multicolumn{9}{|c|}{ Nonessential AA (NEAA) } \\
\hline Asn & 2.0 & 1.8 & 1.5 & 1.7 & 0.20 & 0.28 & 0.37 & 0.45 \\
\hline Asp & 1.4 & 1.7 & 1.4 & 1.4 & 0.16 & 0.84 & 0.45 & 0.28 \\
\hline Gln & 19.5 & 19.3 & 19.7 & 18.5 & 3.53 & 0.68 & 0.70 & 0.73 \\
\hline Glu & 10.7 & 10.7 & 9.2 & 9.5 & 2.20 & 0.17 & 0.86 & 0.37 \\
\hline Gly & 22.6 & 25.2 & 24.1 & 22.2 & 2.31 & 0.83 & 0.34 & 0.79 \\
\hline Pro & 5.5 & 6.1 & 5.9 & 6.5 & 2.18 & 0.26 & 0.97 & 0.50 \\
\hline Ser & 8.3 & 8.5 & 7.9 & 8.4 & 0.63 & 0.89 & 0.85 & 0.46 \\
\hline Tyr & 4.8 & 5.3 & 4.9 & 5.2 & 0.94 & 0.63 & 0.77 & 0.38 \\
\hline Total NEAA & 73.7 & 77.6 & 73.6 & 72.5 & 8.43 & 0.62 & 0.46 & 0.48 \\
\hline
\end{tabular}

${ }^{1}$ Diets include canola meal (CM); $2 / 3$ canola meal and $1 / 3$ dried distillers grains with solubles $(2 / 3 \mathrm{CM}) ; 1 / 3$ canola meal and $2 / 3$ dried distillers grains with solubles $(1 / 3 \mathrm{CM})$, and dried distillers grains with solubles (DDGS). 
Table 5. Amino acid concentrations $(\mu \mathrm{mol} / \mathrm{dL})$ in plasma from the subcutaneous abdominal vein in lactating dairy cows fed experimental diets

\begin{tabular}{|c|c|c|c|c|c|c|c|c|}
\hline \multirow[b]{2}{*}{ Item } & \multicolumn{4}{|c|}{$\operatorname{Diet}^{1}$} & \multirow[b]{2}{*}{ SEM } & \multicolumn{3}{|c|}{$P$-value } \\
\hline & $\mathrm{CM}$ & $2 / 3 \mathrm{CM}$ & $1 / 3 \mathrm{CM}$ & DDGS & & Linear & Quadratic & Cubic \\
\hline Arg & 5.6 & 6.3 & 4.7 & 7.4 & 1.31 & 0.37 & 0.34 & 0.17 \\
\hline His & 3.0 & 3.4 & 2.9 & 3.4 & 0.37 & 0.76 & 0.90 & 0.23 \\
\hline Ile & 5.8 & 6.6 & 5.5 & 6.9 & 0.60 & 0.43 & 0.60 & 0.10 \\
\hline Leu & 8.2 & 9.2 & 7.3 & 9.9 & 0.93 & 0.40 & 0.38 & 0.08 \\
\hline Phe & 1.8 & 2.0 & 1.7 & 2.2 & 0.26 & 0.43 & 0.50 & 0.24 \\
\hline Thr & 8.0 & 8.8 & 6.6 & 8.5 & 2.24 & 0.79 & 0.44 & 0.04 \\
\hline Trp & 2.7 & 2.7 & 1.8 & 2.4 & 0.71 & 0.18 & 0.35 & 0.12 \\
\hline Val & 15.7 & 17.7 & 15.2 & 18.4 & 1.16 & 0.26 & 0.57 & 0.05 \\
\hline Total EAA & 52.0 & 58.6 & 46.2 & 61.6 & 4.13 & 0.36 & 0.27 & 0.01 \\
\hline \multicolumn{9}{|c|}{ Nonessential AA (NEAA) } \\
\hline Asn & 1.0 & 1.2 & 0.7 & 1.1 & 0.17 & 0.67 & 0.51 & 0.06 \\
\hline Ser & 7.9 & 7.8 & 6.3 & 7.5 & 2.49 & 0.29 & 0.30 & 0.11 \\
\hline Tyr & 3.1 & 2.7 & 2.7 & 3.6 & 0.46 & 0.50 & 0.18 & 0.80 \\
\hline Total NEAA & 64.3 & 70.5 & 59.3 & 66.2 & 11.96 & 0.76 & 0.93 & 0.06 \\
\hline
\end{tabular}

${ }^{1}$ Diets include canola meal $(\mathrm{CM}) ; 2 / 3$ canola meal and $1 / 3$ dried distillers grains with solubles $(2 / 3 \mathrm{CM}) ; 1 / 3$ canola meal and $2 / 3$ dried distillers grains with solubles $(1 / 3 \mathrm{CM})$; and dried distillers grains with solubles (DDGS).

linearly with the addition of CM, which corresponded to the arterial linear increase in Lys concentrations that resulted from the higher Lys concentration in CM. There were also corresponding trends $(P<0.10)$ in His and Ile concentrations, as expected from the arterial linear differences.

Extraction efficiency may be the ideal method for evaluating AA requirements because it takes into ac-

Table 6. Arteriovenous differences $(\mu \mathrm{mol} / \mathrm{dL})$ in AA concentrations in plasma from lactating dairy cows fed experimental diets

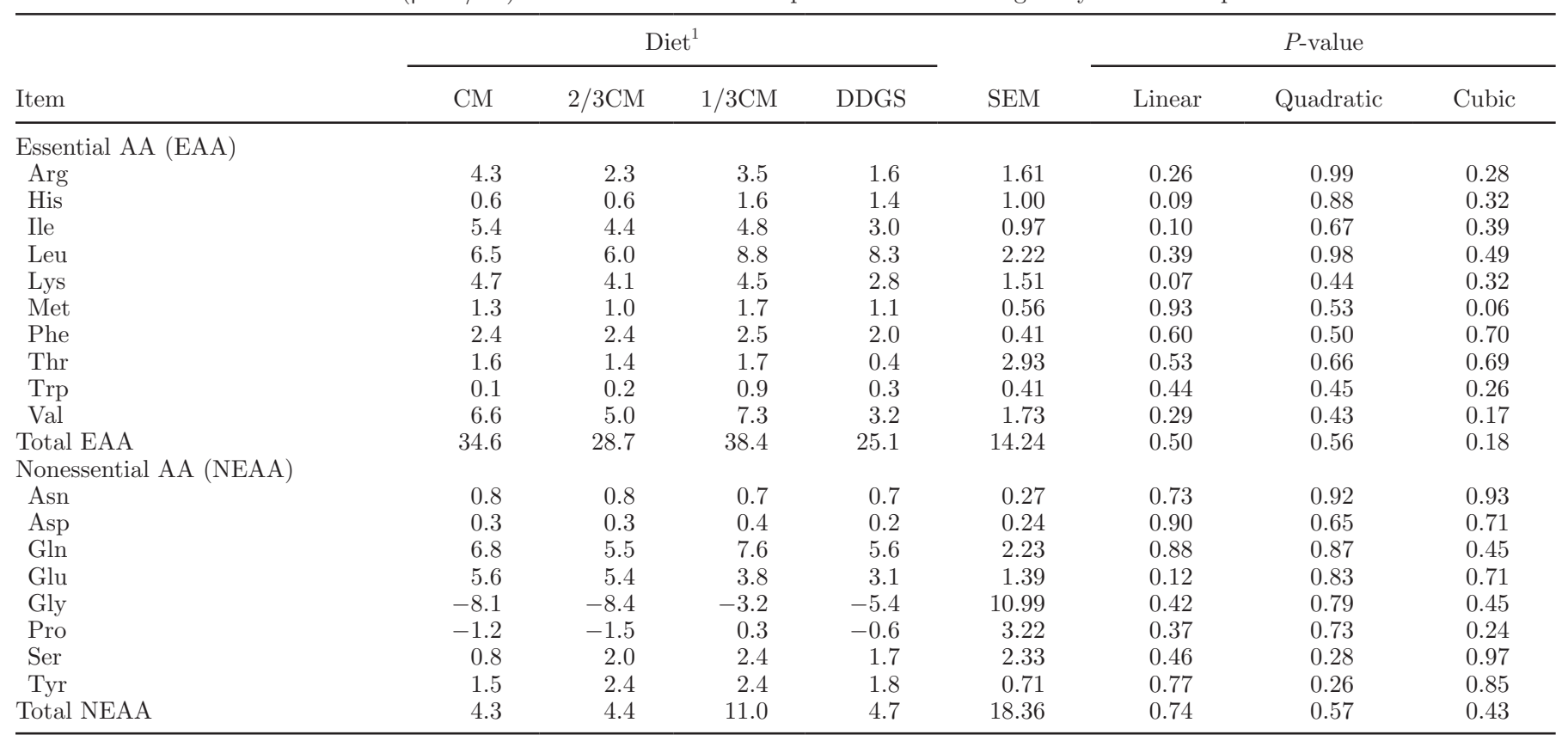

${ }^{1}$ Diets include canola meal $(\mathrm{CM}) ; 2 / 3$ canola meal and $1 / 3$ dried distillers grains with solubles $(2 / 3 \mathrm{CM}) ; 1 / 3$ canola meal and $2 / 3$ dried distillers grains with solubles $(1 / 3 \mathrm{CM})$; and dried distillers grains with solubles (DDGS). 
Table 7. Essential AA extraction efficiency, ${ }^{1} \%$, of dietary treatments

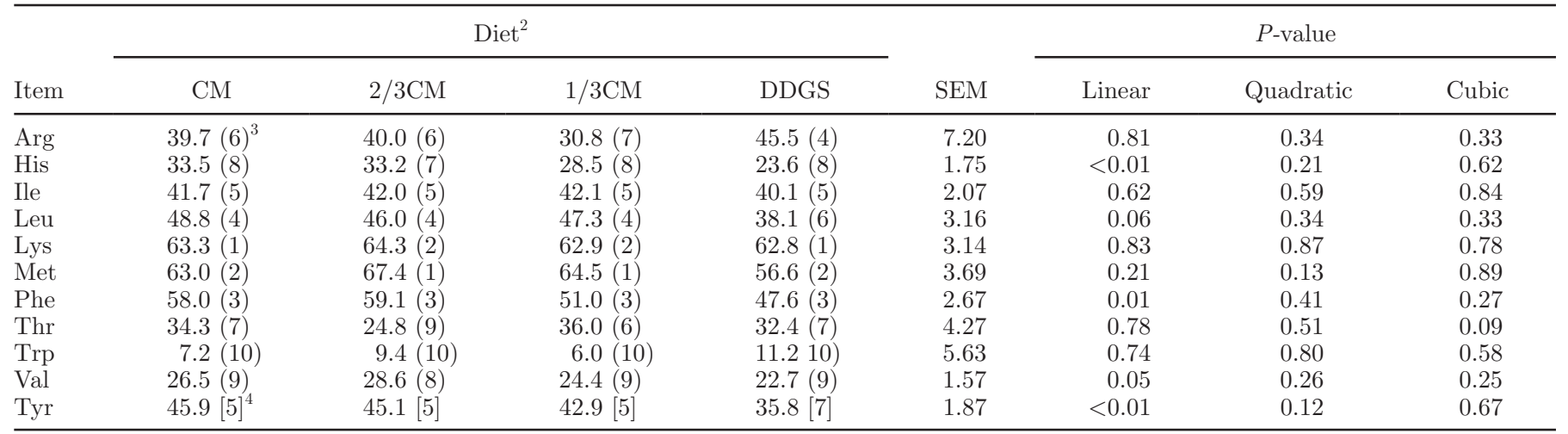

${ }^{1}$ Extraction efficiency $=$ arteriovenous difference of AA $\times 100 /$ concentration of AA in plasma of coccygeal artery.

${ }^{2}$ Diets include canola meal $(\mathrm{CM}) ; 2 / 3$ canola meal and $1 / 3$ dried distillers grains with solubles $(2 / 3 \mathrm{CM}) ; 1 / 3$ canola meal and $2 / 3$ dried distillers grains with solubles $(1 / 3 \mathrm{CM})$; and dried distillers grains with solubles (DDGS).

${ }^{3}$ Numbers in parentheses indicate the apparent order of limiting AA.

${ }^{4}$ Numbers in brackets are the ranking of Tyr if it were considered an essential AA.

count the entire EAA needs of the mammary gland. It includes AA extracted for all needs such as protein synthesis and catabolism (Schingoethe, 1996; Nichols et al., 1998; Kleinschmit et al., 2007b), whereas transfer efficiency and uptake:output ratios consider only AA relative to secretion as milk protein (Kleinschmit et al., 2007b). The possibility of inaccuracies when estimating mammary blood flow is not a concern because mammary blood flow is not a part of the calculations for extraction efficiency, whereas it is included in the other 2 calculation methods.

The extraction efficiency (Table 7) of His, Phe, Tyr, and Val all showed a linear $(P<0.05)$ response to $\mathrm{CM}$, increasing as more $\mathrm{CM}$ was added to the diets. The first-limiting AA for the CM and DDGS diets was Lys, with Met and Phe being the second and third limiting, respectively. This was expected based on previous research (Piepenbrink et al., 1998; Kleinschmit et al., 2007b) with these protein supplements, although
Piepenbrink et al. (1998) indicated that His was third limiting, ahead of Phe, for CM. In the current study, Met was indicated as first-limiting AA, before Lys, in the combination diets. Although all numbers are relatively close, this response may indicate some advantage in feeding a combination of CM and DDGS rather than either alone. Although the numerical values of the extraction efficiencies for the all-CM diet were very close when comparing the first 2 limiting AA, Lys and Met (63.3 vs. $63.0 \%$ ), the difference when comparing Lys and Met in the all-DDGS diet was greater $(62.8 \%$ for Lys vs. $56.5 \%$ for Met). This likely demonstrated a definite difference in the DDGS diet than in the CM diet, and a larger deficiency of Lys in the DDGS diet.

\section{Rumen Fluid Analysis}

Ruminal ammonia concentrations were similar for all diets and were low, reflecting the intended low protein

Table 8. Ruminal ammonia $(\mathrm{mg} / \mathrm{dL})$ and VFA concentrations (mmol/100 mmol) in samples of rumen contents from cows fed experimental diets

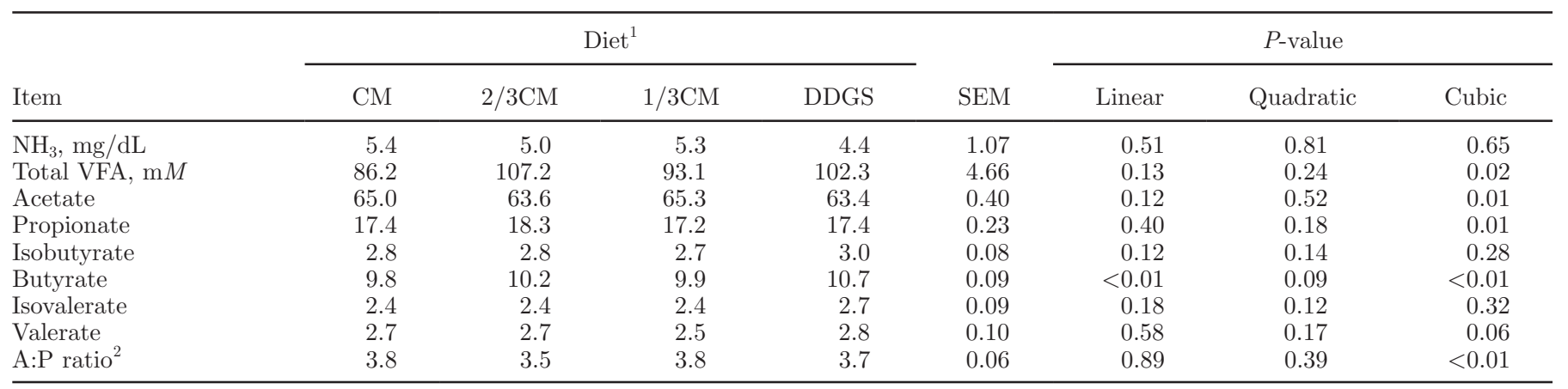

${ }^{1}$ Diets include canola meal (CM), 2/3 canola meal and $1 / 3$ dried distillers grains with solubles $(2 / 3 \mathrm{CM}), 1 / 3$ canola meal and $2 / 3$ dried distillers grains with solubles, $(1 / 3 \mathrm{CM})$, and dried distillers grains with solubles (DDGS).

${ }^{2} \mathrm{~A}: \mathrm{P}$ ratio $=$ acetate to propionate ratio. 
content of the diets (Table 8). However, any differences in ruminal protein degradability among the various diets were not detectable in the ruminal ammonia data. Varying concentrations of CM in the diets had minimal effect on VFA concentrations, although some statistically significant variations were observed. Cubic effects on total VFA concentrations and molar concentrations of acetate, propionate, and butyrate, as well as a linear effect on butyrate, were noted. There was also a cubic effect on the acetate:propionate ratio, following the acetate trend for greater concentrations with $1 / 3 \mathrm{CM}$ and $\mathrm{CM}$. However, these small numerical differences were of questionable biological significance.

\section{CONCLUSIONS}

Results from this study indicate that CM, whether fed as the primary protein supplement or in combination with DDGS, can be used successfully in dairy cattle diets. The DMI, milk production, and milk composition were similar whether the protein supplement was CM, DDGS, or combinations of CM and DDGS. Protein quality was improved when CM and DDGS were combined compared with either fed alone. Blood AA data indicated that $\mathrm{CM}$ is a valuable protein source, with possibly a more desirable AA profile than DDGS.

\section{ACKNOWLEDGMENTS}

The authors gratefully acknowledge the farm crew at the South Dakota State University Dairy Research Unit for caring for the cows and assisting with data collection. Appreciation is acknowledged for partial funding by the US Canola Council, Fargo, North Dakota, as USDA/CSREES Canola Grant \#M7080 and by the Canola Council of Canada, Winnipeg, Manitoba, Canada, as grant \#3X7134.

\section{REFERENCES}

Anderson, J. L., D. J. Schingoethe, K. F. Kalscheur, and A. R. Hippen. 2006. Evaluation of dried and wet distillers grains included at two concentrations in the diets of lactating dairy cows. J. Dairy Sci. $89: 3133-3142$

AOAC. 2002. Official Methods of Analysis. 17th ed. Association of Official Analytical Chemists, Gaithersburg, MD.

Brito, A. F., and G. A. Broderick. 2007. Effects of different protein supplements on milk production and nutrient utilization in lactating dairy cows. J. Dairy Sci. 90:1816-1827.

Chaney, A. L., and E. P. Marbach. 1962. Modified reagents for determination of urea and ammonia. Clin. Chem. 8:130-132.
DePeters, E. J., and D. L. Bath. 1986. Canola meal versus cottonseed meal as the protein supplement in dairy diets. J. Dairy Sci. $69: 148-154$.

Grunau, J. A., and J. M. Swiader. 1992. Chromatography of 99 amino acids and other ninhydrin-reactive compounds in the Pickering lithium gradient system. J. Chromatogr. A 594:165-171.

Kleinschmit, D. H., J. L. Anderson, J. Schingoethe, K. F. Kalscheur, and A. R. Hippen. 2007a. Ruminal and intestinal degradability of distillers grains plus solubles varies by source. J. Dairy Sci. 90:2909-2918

Kleinschmit, D. H. D. J. Schingoethe, A. R. Hippen, and K. F Kalscheur. 2007b. Dried distillers grains plus solubles with corn silage or alfalfa hay as the primary forage source in dairy cow diets. J. Dairy Sci. 90:5587-5599.

Maesoomi, S. M., G. R. Ghorbani, M. Alikhani, and A. Nikkhah. 2006. Short communication: Canola meal as a substitute for cottonseed meal in diet of midlactation Holsteins. J. Dairy Sci. 89:16731677.

Mondina, A., G. Bongiovanni, S. Fumero, and L. Rossi. 1972. An improved method of plasma deproteination with sulphosalicylic acid for determining amino acids and related compounds. J. Chromatogr. A 74:255-263.

NRC. 2001. Nutrient Requirements of Dairy Cattle. 7th rev. ed. Natl. Acad. Sci., Washington, DC.

Nichols, J. R., D. J. Schingoethe, H. A. Maiga, M. J. Brouk, and M. S. Piepenbrink. 1998. Evaluation of corn distillers grains and ruminally protected lysine and methionine for lactating dairy cows. J. Dairy Sci. 81:482-491.

Orth, R. 1992. Sample day and lactation report. DHIA 200 Fact Sheet A-2. Mid-states DRPC, Ames, IA.

Pickering, M. 1989. Ion-exchange chromatography of free amino acids. LC GC 7:484-490.

Piepenbrink, M. S., and D. J. Schingoethe. 1998. Ruminal degradation, amino acid composition, and estimated intestinal digestibilities of four protein supplements. J. Dairy Sci. 81:454-461.

Piepenbrink, M. S., D. J. Schingoethe, M. J. Brouk, and G. A. Stegman. 1998. Systems to evaluate the protein quality of diets fed to lactating cows. J. Dairy Sci. 81:1046-1061.

Robertson, J. B., and P. J. Van Soest. 1981. The detergent system of analysis and its application to human foods. Pages 123-158 in The Analysis of Dietary Fiber in Food. W. P. T. James and O. Theander, ed. Marcel Dekker Inc., New York, NY.

Sánchez, J. M., and D. W. Claypool. 1983. Canola meal as a protein supplement in dairy rations. J. Dairy Sci. 66:80-85.

Schingoethe, D. J. 1996. Balancing the amino acid needs of the dairy cow. Anim. Feed Sci. Technol. 60:153-160.

Schingoethe, D. J. 2008. Use of distillers co-products in diets fed to dairy cattle. Pages 57-78 in Using Distillers Grains in the U.S. and International Livestock and Poultry Industries. B. A. Babcock, D. J. Hayes, and J. D. Lawrence, ed. Midwest Agribusiness Trade Research and Information Center at the Center for Agricultural and Rural Development, Iowa State University, Ames.

Understander, D., D. R. Mertens, and N. Thiex. 1993. Forage analysis procedures. National Forage Testing Association, Omaha, NE.

Van Soest, P. J., J. B. Robertson, and B. A. Lewis. 1991. Methods for dietary fiber, neutral detergent fiber, and nonstarch polysaccharides in relation to animal nutrition. J. Dairy Sci. 74:3583-3597.

Wildman, E. E., G. M. Jones, P. E. Wagner, R. L. Boman, H. F. Troutt Jr, and T.N. Lesch. 1982. A dairy cow body condition scoring system and its relationship to standard production characteristics. J. Dairy Sci. 65:495-501. 